\title{
e-Phaïstos
}

e-Phaïstos

Revue d'histoire des techniques / Journal of the history

of technology

IV-2 | 2015

Patrimoines de l'eau

\section{Rehabilitation of water heritage in the hydroelectric system of Valle de Bravo}

Réhabilitation du patrimoine de l'eau : le système hydro-électrique de la vallée de Bravo

\section{Daniel Maldonado Figueroa}

\section{CpenEdition}

\section{Journals}

Electronic version

URL: http://journals.openedition.org/ephaistos/753

DOI: 10.4000/ephaistos.753

ISSN: 2552-0741

Publisher

IHMC - Institut d'histoire moderne et contemporaine (UMR 8066)

\section{Printed version}

Date of publication: 1 October 2015

Number of pages: 49-53

ISSN: $2262-7340$

\section{Electronic reference}

Daniel Maldonado Figueroa, «Rehabilitation of water heritage in the hydroelectric system of Valle de Bravo », e-Phaïstos [Online], IV-2 | 2015, Online since 28 November 2016, connection on 20 April 2019 URL : http://journals.openedition.org/ephaistos/753 ; DOI : 10.4000/ephaistos.753 


\title{
Rehabilitation of water heritage in the hydroelectric system of Valle de Bravo.
}

\author{
Daniel Maldonado Figueroa \\ Master Erasmus Mundus TPTI, \\ promotion 5 « Cinque Terre »
}

Everyday millions of people in Mexico City use water for cleaning, cooking, and drinking. People sometimes even swim in the water that will soon be used to generate electricity, reaching homes, offices and industries. Each Mexican resident enjoys the advantages and pleasures of water and electricity unaware of its origin, process, or trails.

From Mexico City we will move $140 \mathrm{~km}$ west to Valle de Bravo, a quiet colonial village that became the base for the construction of a dam in the first half of the twentieth century. The dam gave the town a waterside location that became popular for its night time cruises, waterskiing, windsurfing, and fishing. Nowadays, among the tourists, hotels, and wealthy weekend homes, a set of hidden buildings, pipelines, and machinery magnificently relate the origins of Mexican hydroelectricity. Unfortunately, this infrastructure remains abandoned and ignored by most tourists and inhabitants.

To understand the importance of this hydroelectric complex, its history will be recalled interlacing the past of water and electricity in the first hydroelectric system of Mexican design and engineering. A national history of how electricity was produced and water was pumped to nourish the lives of the constantly growing metropolis of Mexico City.

Everything starts when it was demonstrated that electricity could replace gas for lighting. Shortly after, several foreign enterprises set in Mexico to compete in the electric business. Throughout the country, small public power plants produced energy for the mining enterprise and lit small urban settlements. The first textile factories using hydroelectric energy were installed in Guanajuato and Veracruz in 1883. However, the first hydroelectric plant exclusively designed for electric production was settled in Puebla five years later. In 1891 another hydroelectric plant was built for a mining center located in the border between Chihuahua and the United States, becoming the fourth city in the country enjoying electric energy ${ }^{1}$.

Meanwhile, in Mexico City the lighting issue was solved through thermoelectric power plants. Hydroelectricity was not chosen as the basic mean to produce energy because the scarce running water was used to satisfy the constant urban need of water. Due to a previous project to dry the valley of Mexico to enable its urban development, the water supply was solved by artesian aquifers, deep wells under positive pressure that caused water level to rise and allowed to obtain drinkable water to nourish the big city ${ }^{2}$.

At the beginning of the twentieth century, a Canadian enterprise specialized in hydroelectric energy surpassed the water supply troubles, obtained the concession to exploit the energy of the Necaxa River in Puebla, and founded the Compañía Mexicana de Luz y Fuerza (Mexican Light and Power Company). It is important to recall that although the name is in Spanish, the enterprise was from Canada. The Necaxa hydroelectric plant was 
quickly built. By 1905 it was operating and sending energy to Mexico City. It was the first interconnected and most important hydroelectric system in the country built by Mexican manpower ${ }^{3}$.

The owners of the Necaxa system became the most powerful lighting enterprise in the country and bought every other lighting company under the name of Compañía Mexicana de Luz y Fuerza. After acquiring every foreign electric company they founded the Mexican Light Power, a powerful monopole that only supplied energy to industrial cities at high rates, ignoring rural settlements because they were considered unprofitable. Its bad service and increasing rates soon generated protests headed by the new industrial working class of factories, mines, and railways. Together with peasants, they organized themselves to fight for better working conditions. The first strikes took place in mining towns of Cananea and Río Blanco in 1906. These two strikes were a key event in the final years of the regime of Porfirio Díaz, and anticipated the Mexican Revolution from 1910 to 1920. As a consequence, in 1914, the workers of the Mexican Light Power organized the Sindicato Mexicano de Electricistas (Mexican Electricians Union)4.

During the revolution, several neighborhoods suffered from thirst because water supply was unbalanced. Soon after the country was back to peace, new artesian wells and pumping stations were built to regulate water provision. However, the city kept sinking as a consequence of the underground water extraction. Engineers devised new alternatives to supply the city and in 1929 the Lerma river basin, the closest to Mexico City, was foreseen as a possible water supply for the city5.

While the research to develop the hydraulic system that could transport water from the Lerma river basin to Mexico City took place, Lázaro Cardenas negotiated with the electric monopole of Mexican Light Power to start the preliminary works for the construction of a great hydroelectric complex around Valle de Bravo in the state of Mexico. In order to collect the needed investment to accomplish such an ambitious project, the enterprise needed to increase the light rates. The president refused to accept it because such increase could harm the national industry and the Mexican Light Power abandoned the project. To face the energy deficit, the Mexican Electricians Union developed a collective project where the workers, the government, and the users should participate together.

The population of Mexico City grew over one million inhabitants. Neither the water supply nor the electric demand could be satisfied by the Mexican Light Power monopole. More wells were perforated in the desperate and unsustainable search of water while the Mexican Electricians Union looked for the means to accomplish its project to electrify the rural side of the country.

The 12 of February of 1937, a reform in the constitution established that the generation, transmission and distribution systems of electric energy were of national property and declared the foundation of the Comision Federal de Electricidad (Federal Electricity Commission). Its first work was located in Valle de Bravo, a land full of waterfalls, hot springs, and water fountains that evolved changeless through times until technology took advantage of its geographical qualities. The hydroelectric complex of Ixtapantongo was the first hydroelectric plant of Mexican design, organization, engineering and manpower. It took advantage from the Tilostoc River flow and dramatically changed the landscape.

After accomplishing the first work of a future hydroelectric system, the president Lázaro Cárdenas promulgated the electric industry law that set the maximum electric rates. The same year, the feasibility project to bring water from the Lerma River Basin was resumed, and concluded with the building of a distribution and storage system in Chapultepec. While the Chapultepec forest was being excavated, 2,900 hectares of the most productive agricultural fields of Valle de Bravo were flooded to give birth to an amazing dam. With a 


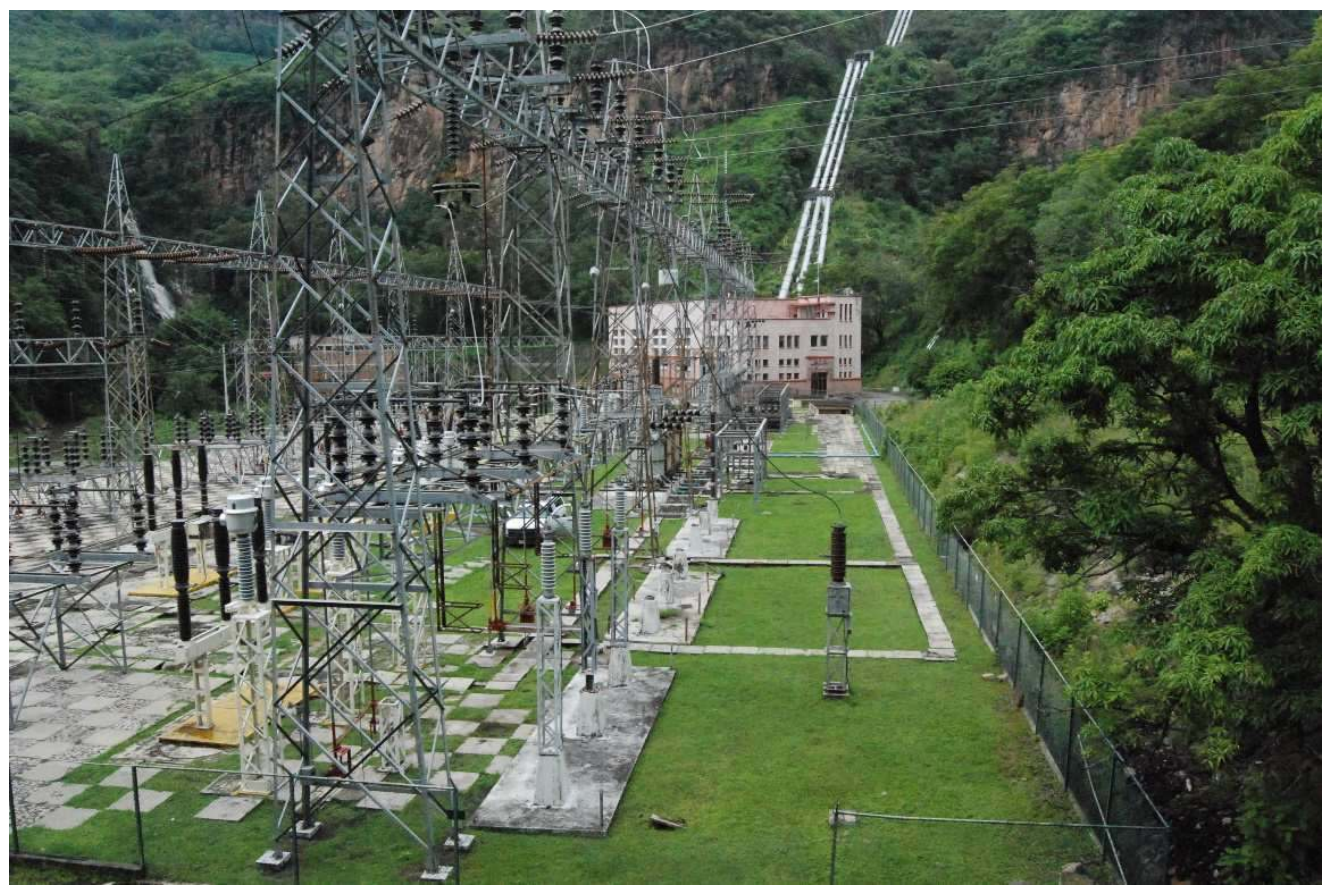

Figure 1 : Ixtapantongo power plant (cliché Daniel Maldonado Figueroa)

curtain of 19 meters and the capacity of 400 million cubic meters, the tank of Valle de Bravo was successfully concluded in $1944^{6}$

When the dam was finished, a second power unit was installed in Ixtapantongo. As the new power unit produced 56,000 extra kilowatts, the remarkable scientist, Nabor Carrillo, demonstrated that Mexico City sank approximately $40 \mathrm{~cm}$ per year because of groundwater extraction. From here on, at the summit of the hydroelectric system, artesian aquifers were forbidden in the central city and the water demand was provided by new wells excavated in the outskirts of the city. At the same time, the Federal Electricity Commission satisfied the growing electric energy demand with the construction of four new power plants: Santa
Bárbara, El Durazno, Héctor Martínez de Meza and Tingambato. Together, they constituted the Miguel Alemán Hidroelectric System.

From the main dam of Valle de Bravo water goes to the power plant of El Durazno. Then, water goes down to the dam of Colorines, which receives water from more rivers. Afterwards, it goes to the power plant of Ixtapantongo and is emptied in a dam with the same name before reaching Santa Barbara. Finally water heads from the tank of Santo Tomás to the power plant of Tingambato, the last of the five power stations.

In 1951 the power plant of Santa Barbara started producing electricity, just as the first flow of water entered the city through the Lerma System honored by the Sump of Dolores, a building constructed to 
commemorate the end of the works of the hydraulic system painted with an underwater mural entitled "Water, source of life" by the world famous muralist, Diego Rivera. On January of 1957 the president Ruiz Cortines inaugurated the last and most powerful of the five power stations integrating the system. After honoring the Federal Electricity Commission and the participating engineers, regional conflicts started around the Lerma region because of water shortage. The decrease of hydraulic resources in the Lerma System brought upraisings, demonstrating the need to bring water from the next water source, the Cutzamala river basin in Valle de Bravo7.

In September of 1960 the president in charge, Adolfo López Mateos, constitutionally nationalized the electric industry. Soon after, the country brought the major stocks from Mexican Light Power with profitable conditions for its owners. This moment symbolized the end of the long fight to nationalize electric energy heroically represented by the infrastructure of Miguel Aleman Hydroelectric system. The system in charge of electrifying the country worked normally for sixteen years until 1976, when its dams and power stations, previously employed to generate hydroelectric energy were chosen as the most feasible water supply to Mexico City. The Cutzamala system reused the set of pipelines and pumping stations to send water to Mexico City. The system was planned in several stages to deal with its bigger difficulty, pumping the water 1,100 meters up to the city. The system soon transformed from energy generator to water provider 8 .

Today, the unused infrastructure is abandoned, leaving unattended a transcendental energetic heritage that dialogues with the history of electricity and water. Its importance and historical significance is unappreciated and unknown by most of the local inhabitants. Moreover, it is located in a city that attracts more than 15,000 tourists weekly9. A successful speculative phenomenon and advertising campaign deleted Valle de Bravo's industrial memory, replacing it with a trivial image of a place of luxury, water sports and leisure. Although the abandonment and progressive deterioration of the hydroelectric infrastructure could lead to its destruction, deleting a piece of memory in Mexico's energetic history, harming a cultural landscape, and leaving a void in social consciousness.

Besides, Valle de Bravo faces a strong problem of social inequality. The wealthy residents invest in luxury houses and leisure activities, while native settlers cope with hunger, poverty and homeless conditions. Paradoxically, while Valle de Bravo and its neighboring municipalities desperately look for projects that foster tourism, the imposing hydroelectric infrastructure stays neglected, waiting to be recycled, reused or destroyed. Most of the 50,000 inhabitants and the 15,000 weekly tourists ignore the existence of Miguel Alemán Hydroelectric System. Those who know about it, steal its materials for a further use, or amuse themselves by drawing graffiti or destroying the infrastructure.

The existing industrial infrastructure could stimulate economic opportunities, promote investments and increase tourism through a reconversion project. Electrical and hydraulic heritage with its cultural landscape stimulates mankind, supports intellectuality, promotes community bonds, and ties together society by reinforcing identity. It develops science, culture, and memory justified by its architectural, engineering, and urban surrounding. Besides, knowledge about the process to produce electricity and distribute water to cities reinforces energy consciousness, and develops a sustainable way of living. 
${ }^{1}$ CAMPOS, Aragón, Leticia. "La electricidad en la ciudad de México y área conurbada: historia, problemas y perspectivas », México, Siglo XXI, 2005.

2 GARZA, Gustavo. Atlas de la Ciudad de México, México, COLMEX. 1986.

3 JIMENEZ, Robert; ROMERO, Javier. Bulletin Numbe 58. TICCIH. 2012. $\quad$ http://www.ticcih.es/wpcontent/uploads/2012/11/ticcih58v9.pdf.

4 CAMPOS, Aragón, Leticia. "La electricidad en la ciudad de México y área conurbada: historia, problemas y perspectivas », México, Siglo XXI, 2005.

5 LEGORRETA, Jorge. Et. Al. El agua el origen de la vida en la tierra, Arquine, 2012.

6 Comisión Federal de Electricidad. «Memoria del Sistema Hidroeléctrico Miguel Alemán de la Comisión Federal de Electricidad ", Suplemento al número 210 de la Revista Mexicana de Electricidad. México, CFE, 1958.

7 Comisión Federal de Electricidad. "Memoria del Sistema Hidroeléctrico Miguel Alemán de la Comisión Federal de Electricidad ", Suplemento al número 210 de la Revista Mexicana de Electricidad. México, CFE, 1958.

${ }^{8}$ LEGORRETA, Jorge. Et. Al. El agua el origen de la vida en la tierra. Arquine, 2012.

9 H. Ayuntamiento de Valle de Bravo y el Gobierno del Estado de México. Plan Municipal de Desarrollo Urbano de Valle de Bravo, Estado de México, México, Julio 2006. 